\title{
Piirteitä perhepalkkauksen kehityksestä Sveitsissä
}

\author{
Kirjoittanut Armas Nieminen.
}

Samaten kuin Ranskassa (ks. ss. 69-71), oli sen naapurimaassa Sveitsissäkin perhepalkkausjärjestelmän käytäntöön tulon välittömänä aiheena vaikeus elättää suurta perhettä tavallisella palkalla, jonka määräsi vain työsuorituksen laatu. Näin tässäkin maassa heräsi ajatus siitä, että myös elatusvelvollisuuden laajuuden eli siis yleensä alaikäisten lasten lukumäärän oli päästävä vaikuttamaan palkan suuruuteen. Tällaisesta sosiaalisesta tarpeesta oli seurauksena, että vuonna 1906 käytäntöön otetuista liittovaltion virkamiesten kalliinajanlisistä pääsivät täysin osallisiksi vain naimisissa olevat, kun naimattomat sen sijaan saivat ne vain puoliksi. E link $\mathrm{k}$ st a n n u s t e n ensimmäisen maailmansodan aikana yhä noustess a ryhdyttiin sitten mainituille $\mathrm{v}$ ir ka miehille vuonna 1916 suorittamaan jokaisesta alaikäisestä lapsesta erityistä lapsi- eli perhelis ää. Vuonna 1927 tämä perheiden taloudellista tukemismuotoa koskeva lainsäädäntö uusittiin. Lapsilisiä maksetaan siten siviilisäätyyn ja palkan määrään katsomatta liittovaltion virkamiehille jokaisesta heidän huollettavanaan olevasta 18 vuotta nuoremmasta lapsesta. Niillä paikkakunnilla, joilla elinkustannukset ovat suuremmat kuin keskimäärin maassa, suoritetaan virkamiehille lisäksi erityisiä kalliinpaikanlisiä, mutta naimattomat saavat tällöin vain $75 \%$ sitä summasta, mihin naimisissa olevat ovat oikeutettuja. 
Myös osa liittotasavallan pikkuvaltioista eli kantoneista samoinkuin kunnistakin maksaa omille virkamiehilleen lapsilisiä, vaikka järjestelmän yksityiskohdat vaihtelevatkin, osan taas tyytyessä ottamaan perhesuhteet huomioon vain siten, että palkkojen alennusten on annettu raskaammin kohdistua perheettömiin kuin perheellisiin.

Yksityisissä työsuhteissa perheiden toimeentulon tiukentumisen aiheuttaman paineen täytyi tulla varsin suureksi, ennenkuin niissä ryhdyttiin toteuttamaan perhepalkkausperiaatetta, sillä Sveitsissä samoinkuin monessa muussakin maassa sekä työnantajat että työntekijät ovat pitäneet parempana suorituspalkkausperiaatteen johdonmukaista noudattamista, kun he ovat pelänneet palkkojen vapaan kehityksen mahdollisuuksien heikkenemistä ja valtiojohtoisuuden lisääntymistä tällä alalla. Ensimmäisen maailmansodan aikana elinkustannusten kohoaminen kuitenkin johti ilmeiseen epäsuhtaan perheiden tulojen ja niiden välttämättömien menojen kesken, ja ratkaisun saamiseksi tähän ongelmaan oli työnantajille edullisinta antaa lisäpalkkoja vain perheellisille, kun palkankorotuksia ei kerran voitu välttää. Myös työntekijät katsoivat parhaaksi työehtosopimuksissaan suostua perhepalkkausperiaatteen hyväksymiseen, jotta edes niiden palkkoja voitaisiin nostaa, joille se oli kaikkein välttämättömintä, kun mahdollisuuksia yleiseen palkkojen korottamiseen ei ollut. Tällaiset sopimukset jäivät kuitenkin vain väliaikaisiksi, sillä rauhan palattua ja taloudellisesti parempien aikojen koittaessa lapsilisät taas jäivät pois käytännöstä yksityisissä työsuhteissa.

Sveitsin samoinkuin muidenkin länsi-, keski- ja pohjoisEuroopan maiden yhteiskuntakehityksessä ilmeni kuitenkin ennen pitkää uusi tekijä, joka jälleen viritti kysymyksen perhepalkkausjärjestelmän käytäntöön ottamisesta: syntyneisyyden alenemisesta aiheutuvat väestöpoliittiset pulmat. Maan tilastomiehet kiinnittivät jo vuodesta 1923 lähtien huomiota tällaiseen kehitystaipumukseen. Syntyneisyyden aleneminen alkoi länsi-Sveitsissä, joka sivistyksellisesti liittyy Rans- 
kaan, ja niin Vaud'in kantonissa katsottiin tarpeelliseksi muodostaa vuonna 1923 ranskalaisen esikuvan mukaan erityinen järjestökin, Pro Familia, väestöpoliittisen toiminnan edistämiseksi. Samanlaisia järjestöjä perustettiin sitten myöhemmin muissakin osavaltioissa, saksalaisessa Sveitsissä kuitenkin vasta seuraavalla vuosikymmenellä.

On luonnollista, että Sveitsissä käytännöllistä väestöpolitiikkaa suunniteltaessa huomio kiintyi nimenomaan suureen län- . tiseen naapurimaahan Ranskaan, missä perhepalkkausjärjestelmä jo kauan oli ollut väestöpolitiikan merkittävin toimintamuoto ja mistä käsin harjoitettu väestöpoliittinen valistustyö ja propaganda tunnettiin ranskalaisessa Sveitsissäkin. Täten edellisessä kirjoituksessa selostettu $\mathrm{ranskalain} \mathrm{en} \mathrm{vapa} \mathrm{a} \mathrm{h-}$ toisuuden perustalle rakentuva perhepalkkausjärjestelmä tasausrahasto 1 neen e 11 - kas soin e e n alkoi levitä Sveitsiinkin. Vuonna 1937 tällaiset rahastot, joihin oli liittynyt jo noin 70 teollisuuslaitosta, jakoivat lapsilisiä noin 1000 perheelle.

Vuonna 1939, juuri uuden maailmansodan aattona, väestöpoliittinen toiminta Sveitsissä sai uutta yllykettä, kun valtioliiton tilastoviraston toimesta tehtiin tunnetuksi maan väkiluvun kehityksen ennakkolaskelmia. Näiden mukaan aviollisen hedelmällisyyden pysyessä sillä matalalla tasollaan, mihin se oli painunut, Sveitsissä kuolleisuus 12 vuoden kuluttua oli ylittävä syntyneisyyden. Seurauksena oli ilmeinen väestöpoliittinen herääminen. Väestökysymystä alettiin käsitellä julkisessa sanassa ja kirjallisuudessa, ja vapaa kansalaistoiminta tällä alalla vilkastui. Erityisesti Sveitsin sosiaalipoliittisiin järjestöihin, Schweizerische Vereinigung für Sozialpolitik ja Schweizerische Gemeinnützige Gesellschaft, varsinkin viimeksi mainitun jaostoon Familienschutzkommission, tällaiset harrastukset keskittyivät. Liittovaltion valtiopäivillä tehtiin myös välikysymys siitä, mihin väestökriisin johdosta oli ryhdyttävä, ja liittovaltion korkeimmassa toimeenpanevassa hallintoelimessä, liittoneuvostossa, ryhdyttiin valmistelemaan väestöpoliittisia toimenpiteitä turmiollisen väestönkehityksen ehkäisemiseksi. 
Samoinkuin edellisen suursodan aikana taloudellinen ahdinko ja perheellisten toimeentulon vaikeutuminen nytkin tuli jouduttamaan väestöpoliittisten näkökohtien sanelemaa asiain kulkua niissäkin kantoneissa, joissa väestönkehitys ei vielä näyttänyt mitenkään uhkaavalta. Nimenomaan juuri näissä maan lapsirikkaissa osissa todettiin, että köyhäinapu meni etupäässä suurille perheille, joiden huoltajat eivät omin voiminsa kyenneet hankkimaan edes toimeentulominimin mukaista perheensä elatusta. Syksyllä 1940 Bernissä kokoontuneessa väestö- ja perheensuojakonferenssissa siihen asti toteutettujen väestöpoliittisten toimenpiteiden, erityisesti perheellisten verohelpotusten, liittovaltion, kantonien ja kuntien palveluksessa olevien virkamiesten perhelisien sekä äitiysavustusten edelleen kehittäminen otettiinkin sitten pohdittavaksi ja suunniteltiin yleisen perhepalkkausjärjestelmän toteuttamiseksi pakollisten tasausrahastojen perustamista. Samanlaisia esityksiä niin ikään tehtiin eräiden poliittisten puolueiden taholta. Nyt alettiin myös yhä enemmän tähdentää sitä, että lapsilisien ei olisi rajoituttava vain joillekin ammattialoille, vaan niiden pitäisi olla yleisiä ja että ei ollut summittaisesti kiinnitettävä huomiota vain syntyneisyyden lisäämiseen, vaan olisi pidettävä silmällä myös väestön laatua. Samaten korostettiin, että perheiden tukeminen ei saa jäädä huoltotoiminnaksi, vaan että lapsilisiä on pidettävä sosiaalisen oikeudenmukaisuuden vaatimana korvauksena perheille niiden suorittaessa tärkeätä yhteiskunnallista tehtäväänsä uuden sukupolven kasvattajana.

Tällaisen vilkkaan väestöpoliittisen harrastuksen virittyä alkoi myös ilmaantua pyrkimyksiä osavaltioissa alkunsa saaneiden perhepalkkausjärjestelmien kehityksen alistamiseksi koko liittovaltiossa yhtenäisen johdon alaiseksi. Vuoden 1941 lopulla asian hyväksi ryhdyttiin puuhaamaan Sveitsin valtiosäännölle ominaista »k a n s a n a lo i t e $t \mathrm{t}$ a», ja seuraavan vuoden toukokuussa voitiinkin sitten jättää liittokansliaan yli 170.000 eri kirkkokuntiin ja poliittisiin puolueisiin lukeutuvan kansalaisen allekirjoittama tällainen aloite sperheen puolesta». Aloitteessa suositeltiin liittovaltion valtiosäännön täydentämistä 
sellaisella säännöksellä, että perhe valtion ja yhteiskunnan perustuksena oli oleva liittovaltion erikoissuojeluksessa ja että liittohallituksen oli pyrittävä edistämään kantonien ja kuntien pyrkimyksiä yleisen perhepalkkausjärjestelmän voimaan saattamiseksi tarvittaessa itst: perustamalla tasausrahastoja. Epäluulot tällaisia pyrkimyksiä kohtaan elivät kuitenkin voimakkaina sekä työnantajien että työntekijäin keskuudessa etenkin saksalaisessa Sveitsissä, mutta vähitellen vastarinta heikkeni. Valtiopäivät hyväksyivät kansanaloitteen keväällä 1945, ja kansanäänestyksessä seuraavassa marraskuussa hyväksyminen annettiin 548.000 äänellä 170.000 vastaan. Perhepalkkausjärjestelmä oli näin voittanut puolelleen kansan enemmistön. Uudistuksen mukaan liittohallitus myös sai oikeuden perustaa keskustasausrahaston ja säätää tasausrahastot pakollisiksi koko väestölle tai joillekin väestöryhmille. Taloudellisiin suorituksiin tuli sekä liittovaltiolla että kantoneilla olemaan velvollisuuksia.

Samanaikaisesti kuin perhekustannusten tasauksen aate on Sveitsissä voittanut yhä useampia kannattajia, on perhepalkkausjärjestelmän käytännöllinen toteuttaminen levinnyt yhä laajemmalle. Yleiskuva tässä suhteessa on kuitenkin varsin kirjava, kun eri elinkeinohaarat ja osavaltiot ovat kehittäneet omia vapaaehtoisuuden pohjalle rakentuvia järjestelmiään, eikä näitä liittohallituksen toimesta ole pyritty yhdenmukaistamaan. Ensimmäinen koko liittovaltion a luee 11 a tietyn elinkeinohaaran puitteissa toimiva tasausrahasto saatiin aikaan toukokuussa 1941 kone- ja metalliteollisuuden piirissä, mutta rajoittuivat kuukautiset lapsilisät tällöin vain perheiden kolmansiin ja sitä seuraaviin lapsiin. Samanlainen järjestely toteutettiin pian myös panimoalalla. Kelloteollisuuden piirissä ja kirjapainoalalla alettiin vuonna 1942 antaa lapsilisiä jokaisesta alaikäisestä lapsesta. Jotkut tietyn elinkeinohaaran keskuudessa toimivat rahastot rajoittuvat vain muutamiin tai yhteen kantoniin. Ensimmäinen a lu e ellisella pohjalla toimiva yleinen tasausrahasto perustettiin Valais'n osaval- 
tiossa vuoden 1942 alussa. P a k o 11 is eksi kuuluminen tasausrahastoihin tehtiin ensin Vaudin kantonissa keväällä 1943 ja vuotta myöhemmin Genève'n osavaltiossa sekä sitten vuonna 1945 Fribourg'in, Neuchâtel'in ja Luzern'in kantoneissa. Näistä osavaltioista vain viimeksi mainitussa on saksankielinen väestön enemmistö. Muut viisi kantonia ovatkin Sveitsin 19 koko- ja 6 puolikantonista ainoita, joissa asukkaiden enemmistö on ranskankielistä. Osavaltioissa, joissa järjestelmä on pakollinen, sellaiset työnantajat, joiden edustamalla alalla ei ole tasausrahastoa, kuuluvat kantonien perustamiin yleisiin rahastoihin.

Vuoden 1945 alussa Sveitsissä oli kaikkiaan 196 tasausrahastoa, joista vain 18 käsitti koko maan ja 178 toimi pienemmällä alueella. Rahastoihin oli liittynyt lähes 39.000 yritystä, joissa oli työssä 290.000 työntekijää. Koko maan käsittävät rahastot olivat kuitenkin suurimmat, ja niihin kuuluvissa yrityksissä työskentelikin 168.000 työntekijää, joten siis vain 122.000 työntekijää palveli yrityksissä, jotka olivat liittyneet rajoitetummalla alueella toimiviin rahastoihin.

Vuonna 1944 suoritetun 101 tasausrahastoa koskevan tutkimuksen mukaan toimi 84:stä eri ammattialojen rahastosta 46 teollisuuden ja käsityön, 14 kaupan, 9 vapaiden ammattien ja 15 muiden ammattien alalla. Rahastot suorittivat lapsi- ym. lisinä vuodessa noin 20 miljoonaa frangia. Sodan jälkeen tämä summa on kuitenkin kohonnut moninkertaiseksi, sillä sodan aikana asepalvelukseen kutsutut virkamiehet saivat perheavustuksia valtiolta eivätkä tasausrahastoista.

Lapsilisien rahoitus tapahtuu yleensä niin, että työnantajat suorittavat rahastoille tietyn prosentin maksamistaan bruttopalkoista. Em. vuoden 1944 tutkimus osoitti, että 63 rahastoon kuuluvien keskuudessa tämä prosentti oli $1 / 2-5$ keskimäärän ollessa $1^{1 / 2}-2^{1 / 2}$. Tätä suuremmaksi prosentti kohosi vain 8 tapauksessa. 27 rahastoon liittyneiden työnantajien maksun suuruus oli riippuvainen työntekijäin luvusta kuukausimaksun ollessa $1-29$ frangia. Joissakin tapauksissa yritykset suorit- 
tivat tietyn summan jokaiselta työtunnilta, keskimäärin 6 centimeä. Eräässä tapauksessa sekä työnantajat että työntekijät maksoivat 1 prosentin bruttopalkoista, joissakin taas työnantajat $1 / 2-1$ prosenttia ja työntekijät 2 prosenttia. 5 tapauksessa tämä rahoitusmaksun suuruus oli riippuvaz̆nen työntekijäin lapsiluvusta, mutta tällainen järjestelmä oli väistymässä.

Muutamat rahastot eivät suorita lapsilisiä lainkaan niille työntekijöille, jotka saavat kuukaúsipalkkaa. Toiset taas antavat paitsi lapsilisiä myös avustuksia muidenkin läheisten omaisten huoltajille, joissakin tapauksissa myös työntekijän solmiessa avioliiton tai lapsen syntyessä. Eräässä tapauksessa maksetaan määrätyin edellytyksin avustus jokaiseksi jouluksi.

Myös lapsilisän määrä vaihtelee suuresti, 6-25 frangin välillä kuukaudessa. Jotkut rahastot maksavat lisiä vasta toisesta lapsesta ja kaksi rahastoa vasta kolmannesta lapsesta alkaen. Yleisenä ikärajana lisän saannille on 18 vuotta, muutamissa rahastoissa kuitenkin vain 15 ja parissa 20 vuotta. Työkyvyttömille tai koulua käyville lapsille saatetaan lisiä maksaa myöhempäänkin ikään saakka. Rajoituksia lapsilisän saannissa aiheutuu joissakin tapauksissa myös siitä, että lapsella on omaa työtuloa.

Tasausrahastojen käytännöllinen hoito on yleisesti työnantajilla ja työntekijöillä yhteisesti. Niissä osavaltioissa, missä rahastot ovat pakollisia, joko kantonien virkamiehet tai rahastojen oma henkilökunta huolehtivat niiden hoidosta. Kaikkia rahastoja koskee pakollinen tarkastus.

Sveitsin oloja koskevista kirjoituksista ilmenee, että vaikka työväestön reaalipalkat jo ovat kohoamassa sodan edelliselle tasolle ja vaikka rauhanomaiset olosuhteet muutenkin ovat palanneet Sveitsin elinkeinoelämään, ei tällä kerralla ole ilmaantunut perhepalkkausjärjestelmien vastaisia pyrkimyksiä niidenkään keskuudessa, jotka huoltovelvollisuutta vailla ollen eivät itse henkilökohtaisesti tule osallisiksi järjestelmän tuottamista eduista. Tätä seikkaa pidetään todistuksena siitä, että perhekustannusten tasaus Sveitsissäkin on omaksuttu pysyväiseksi 
sosiaaliseksi toimintamuodoksi, ja katsotaan, että perhepalkkausjärjestelmä on maassa leviävä yhä laajemmalle. Jos näin käy, tällainen järjestelmä on Sveitsissäkin todennäköisesti osoittautuva välivaiheeksi yleisiin lapsilisiin johtavassa kehityksessä, niinkuin järjestelmän emämaissakin, Ranskassa ja Belgiassa on käynyt (ks. s. 84).

\section{Kirjallisuutta.}

Befolkningspolitik i utlandet, En redogörelse utarbetad av 1941 års befolkningsutredning. Statens offentliga utredningar (SOU) 1944: 26, Tukholma, ss. 56, 63 .

Betänkande angående gift kvinnas förvärvsarbete m.m. avgivet av kvinnoarbetskommitten, SOU 1938: 47, ss. 148, 151.

Family Allowance Schemes in 1947. International Labour Review (Geneva) 1948 , ss. $315-333,456-477$.

Gygax, Paul, Sozialpolitik und Familienschutz. Der Schutz der Familie, Festgabe für August Egger, Zürich 1945, ss. 31-43.

Harmsen, H., Schweizer Volksinitiative für die Familie. Archiv für Bevölkerungswissenschaft und Bevölkerungspolitik (Leipzig) 1943, ss. 104 -109 .

Hydén, Sven, Familjelönen har slagit igenom i Schweiz. Industria (Tukholma) 1946, n:o $11-12$, ss. $64-68,84-86$.

Michot, Albert, Politique sociale et démographique en Suisse. Population (Pariisi) 1947, ss. 533-546.

Nef, Hans, Kantonale Gesetze über Familienausgleichskassen. Der Schutz der Familie, ss. $339-375$.

Zeck, Hans $F$, Die bevölkerungspolitischen Massnahmen der Schweiz. Archiv für Bevölk. wiss. und Bev. pol. 1940, ss. 179-181. 